\title{
Non-Verbal Communication on Imperative Speech in Japanese and Indonesian
}

\author{
Marina Indahningrum*, Djodjok Soepardjo, Roni \\ ${ }^{*}$ Program Studi Pendidikan Bahasa Jepang, Universitas Negeri Surabaya, Indonesia \\ e-mail: marinkoindah@gmail.com
}

\begin{abstract}
Communication between humans is called interpersonal communication. Communication is built by repeating encoding where the speaker conveys the message to the recipient and decoding where the receiver reads it. The delivery of messages is broadly divided into verbal communication and nonverbal communication. Japan is a country that uses nonverbal communication more than Indonesia. Nonverbal communication helps speakers to emphasize pragmatic meaning explicitly and also to apply some assumptions in the mind of the interlocutor. Therefore, this research was conducted by researchers to describe forms of nonverbal communication in Japanese and Indonesian imperative speech; describe the similarities and differences in nonverbal communication forms of imperative speech in Japanese and Indonesian. This study uses a descriptive method to describe and synchronize the differences and similarities of nonverbal communication between the two countries. The results obtained are that verbal communication is found to strengthen imperative sentences, as follows in dynamic nonverbal communication, such as in imperative expressions in

Keywords:

Verbal communication; Imperative sentences; Dynamic non-verbal communication;

Static non-verbal

communication

\section{Article Info:}

First received:

25 July 2021

Available online:

30 December 2021 through the head, namely nodding, then imperative sentences as well. use more facial expressions with a smile. In contrast to Indonesian, the imperative sentences used are supported by non-verbal communication, namely dynamic nonverbal communication using limb gestures on the palms of the hands. This, apart from the differences, there are similarities in verbal communication used to suppress verbal communication in Japanese and Indonesian, that is, every communication is always accompanied by slight movements of the limbs. Furthermore, statistical nonverbal communication in Japanese is a cultural characteristic found in clothing.
\end{abstract}

\section{PENDAHULUAN}

Memerintah bukanlah hal yang mudah dilakukan. Tindak tutur meminta mengandung daya ilokusioner. Bentuk-bentuk tuturan yang berbeda banyak ditemukan dalam tuturan memerintah yang diproduksi oleh masyarakat Jepang ketika mengggunakan bahasa Jepang. Sebagian besar dari penyampaian tuturan imperatif dibantu oleh komunikasi non verbal untuk menekankan maksud dari tuturan tersebut. Hasil penelitian (Suzuki, 2013: 6) mengatakan bahwa saat berkomunikasi verbal lisan, secara visual didominasi komunikasi nonverbal 90\%.

Dalam komunikasi sehari-hari komunikasi nonverbal dapan mempengaruhi penegasan maksud komunikasi. Maksud komunikasi dalam merujuk pada makna pragmatis dari penutur atau mitra tutur. Makna pragmatik muncul melalui suatu percakapan antara penutur dan mitra tutur. Komunikasi nonverbal membantu penutur untuk menekankan makna pragmatik secara eksplisit dan juga untuk menerapkan beberapa asumsi di dalam pikiran lawan bicara (Kaluska, 2013:218). Dalam berkomunikasi masyarakat Jepang memiliki perbedaan yang menyebabkan tuturannya tidak mematuhi kesantunan dalam berbahasa Indonesia.

Perbedaan penyampaian komunikasi nonverbal tersebut menjadi penyebab utama yang menyebabkan kegagalan dan kesalah pahaman dalam komunikasi. Salah satunya pada kalimat imperatif, kalimat imperatif sering digunakan dalam berbagai kesempatan untuk komunikasi, terutama dalam kehidupan seharihari. Kalimat tersebut dipakai oleh guru saat 
memberi arahan, perintah, dan larangan kepada lawan tutur. Beberapa perbedaan komunkasi nonverbal tersebut mengakibatkan tuturan imperatif bahasa Jepang dilabeli oleh penutur Indonesia sebagai tidak sesuai, bahkan tidak santun digunakan dalam sebuah tindak tutur. Tidak dapat dipungkiri bahwa bentuk-bentuk komunikasi nonverbal yang berbeda tersebut karena perbedaan etnis atau budaya yang ada diantara kedua negara. Oleh karena itu, peneliti memilih untuk meneliti tentang komunikasi nonverbal pada tuturan imperatif bahasa Jepang dan bahasa Indonesia. Berdasarkan latar belakang di atas, permasalahan dalam penelitian ini adalah sebagai berikut. Pertama, bentuk komunikasi nonverbal pada tuturan imperatif dalam bahasa Jepang yang dihasilkan oleh penutur asli Jepang. kedua, Bagaimana bentuk komunikasi nonverbal pada tuturan imperatif dalam bahasa Indonesia yang dihasilkan oleh penutur asli bahasa Indonesia. Ketiga, Bagaimana persamaan dan perbedaan komunikasi nonverbal antara bahasa Jepang dan bahasa Indonesia.

Kajian mengenai tuturan imperatif dalam bahasa Indonesia, Rahardi (1999) menyatakan bahwa permintaan termasuk ke dalam salah satu wujud pragmatik imperatif. Wujud-wujud pragmatik imperatif yang lain adalah perintah, suruhan, permohonan, desakan, bujukan, himbauan, persilaan, ajakan, izin, mengizinkan, larangan, harapan, umpatan, pemberian ucapan selamat, anjuran, dan ngelulu. Selain itu ada penelitian yang lain yakni kalimat imperatif pernah diteliti oleh Ellinda Triariska (2015) Analisis Kalimat Imperatif dalam Bahasa Gayo, Novita Ramadhani. Ogawa (1995) melalui peran bahasa nonverbal mengklasifikasikan keintiman dengan metode analisis perbandingan untuk permintaan maf. Sedangkan dalam penelitian kali ini, peneliti ingin membahas tentang komunikasi nonverbal yang membantu menekan maksud dari tuturan imperatif melalui kajian etnografi pragmatik. Selain itu Joon (2012) melalui peran bahasa nonverbal menyingkronkan ucapan terima kasih dan salam antara mahasiswa universitas Jepang dan korea. Meskipun begitu dalam pembelajaran bahasa Indonesia komunikasi nonverbal juga digunakan oleh Dosen untuk membantu penekanan komunikasi verbal Saputra (2020) dan mempermudah proses pengajaran dalam kelas.Penelitian kali ini membahas tentang bagaimana komunikasi nonverbal dapat membantu seseorang untuk menekankan makna eksplisir dari tuturan imperatif yang disampaikan kepada lawan tutur.

Pada penelitian ini penutur dan mitra tutur berasal dari budaya yang berbeda, tidak hanya komunikasi verbal saja tetapi juga perlu adanya pengetahuan dan pemahaman terhadap komunikasi nonverbal. Begitu juga dengan komunikasi yang terjadi antara orang Indonesia dengan orang Jepang. Pentingnya mengetahui perbedaan komunikasi nonverbal antara lain dalam kebiasaan mengucap salam, penimpalan dalam berbicara, pandangan mata, cara menyentuh lawan bicara, maupun kebiasaan yang berhubungan dengan masalah komunikasi. Perbedaan-perbedaan tersebut perlu diteliti, diketahui dan dipahami demi kelancaran dalam komunikasi, karena kalau tidak bisa terjadi kesalahpahaman yang fatal, yang bisa berakibat buruk dalam perkembangan kerjasama perusahaan yang juga merupakan penjabaran kerjasama antar Negara.

\section{TINJAUAN PUSTAKA}

Etnografi komunikasi adalah disiplin ilmu yang digunakan untuk mengkaji pola pemakaian bahasa pada budaya tertentu yang berhubungan dengan perilaku tutur, pilihan yang dilakukan penutur, topic dan setting pembicaraan dalam komunikasi. Hymes (1962) mengemukakan bahwa etnografi komunikasi adalah kajian linguistik yang menekankan dimana konteks itu terjadi. Artinya, etnografi komunikasi merupakan kajian yang berfokus pada bahasa dalam perilaku komunikatif masyarakat yaitu bagaimana cara-cara bahasa dalam komunikasi dipergunakan dalam konteks tertentu, selain itu etnografi komunikasi juga merupakan proses seseorang atau kelompok dalam berkomunikasi dilingkungannya dengan konteks tertentu.

Hymes (1974:53-62) mengklasifikasikan peristiwa ujar dan tinak ujar. Faktor yang melatarbelakangi sebuah komunikasi dikelompokkan menjadi 8 bagian, yang diakronimkan SPEAKING. Setting merupakan tempat dari keadaan terjadinya komunikasi. Participant yang dimaksud adalah narasumber, mitra tutur serta pendengar dalam konteks terjadinya komunikasi. End merupakan tujuan pembicaraan yaitu merupakkan keinginan yang akan dicapai penutur dalam komunikasi misalnya tindakan nego oleh penutur untuk 
mendapatkan kesepakatan dalam perjanjian. Act bentuk dari ujaran atau urutan tindakan, berkenaan tuturan tuturan sendiri berupa langsung dan tak langsung. Key merupakan kunci yang digunakan saat komunikasi terjadi. Suasana pada konteks tertentu berpengaruh pada ekspresi wajah ketika komunikasi terjadi. Ekspresi wajah dapat menggambarkan kekecewaan, kegembiraan, kemarahan dan lain sebagainya. Instrument merupakan alat untuk komunikasi, alat ini berguna sebagai cara mendapatkan output pada tuturan. Norm disebut juga dalam peraturan yang harus disepakati bersama, misalnya berupa kesopan atau aturan komunikasi. Genre yang dimaksud adalah cara yang dinaksn untuk menyampaikan komunikasi. Seiring dengan pendapat (Muriel, 2003: 2) bahwa etnografi memfokuskan karakter interaksi pada suatu kelompok yang mempunyai pola tersendiri. Pendekatan etnografi komunikasi bertujuan menggali dan menetapkan berbagai cara dalam komunikasi. Kajian ini menjadi bagian dari cara hidup yang berbeda dan menganalisa pola komunikasi sebagai pengetahuan budaya dan perilaku.

Komunikasi merupakan pertukaran informasi dilakukan oleh individu atau lebih yang disampaikan secara verbal. Namun, penyampaian informasi verbal didukung dengan kamonukasi nonverbal. Komunikasi menjadi bagian penting manusia untuk mengekspresikan pikiran, pengetahuan, perasaan, keterampilan dan gagasan (Bunglowala, 2015: 371). Dalam proses komunikasi penutur tidak hanya mengirim sebuah sinyal-sinyal tanpa mengandung pesan melainkan proses komunikasi yang terjadi dilandasi pada adanya sistem signifikansi (Eco, 2016:8). Sistem signifikansi yang dimaksud adalah kombinasi antara sinyal dengan kode-kode tertentu. Komunikasi perlu memiliki sebuah tujuan yang tidak hanya stimulus tetapi merangsang adanya respon sehingga komunikasi dua individu berjalan dengan baik.

Komunikasi interpersonal merupakan komunikasi manusia yang melibatkan hubungan saling mempengaruhi yang bertujuan untuk mengelola sebuah hubungan (Beebe, 2009:5). Komunikasi tersebut menganggap tidak hanya komunikasi bertukar informasi dan gagasan, tetapi komunikas lebih-lebih menjadi media untuk semakin meningkatkan hubungan kekerabatan. Komunikasi non verbal sendiri terdiri dari dua jenis yaitu pertama Komunikasi nonverbal dinamis merupakan komunikasi nonverbal bergerak yang menyampaikan pesan dan bermakna (sign language). Wang (2009) mengklasifikasikan komunikasi nonverbal yang berakar dari Ruesch dan Kees (1961) menjadi tujuh, yaitu (1) body behavior atau sikap tubuh; (2) general appearance and dress atau asesoris umum dan pakaian; (3) body movement atau gerak tubuh; (4) posture atau postur; (5) space and distance atau jarak dan spasial; (6) silence atau kesunyian; dan (7) sign and symbols atau tanda dan simbol. Gerakan dan posisi tubuh secara khusus mencakup (1) gestur; gerakan anggota badan, tangan, kepala, telapak, dan kaki, (2) ekspresi wajah seperti senyuman, (3) kontak mata; kedipan, arah, tatapan (Knapp, 2013:13).

Kedua, komunikasi nonverbal Statis merupakan komunikasi nonverbal tidak bergerak, tidak menyertai tuturan verbal. Komunikasi nonverbal statis adalah symbol tertentu dalma konteks kultural tertentu. Beberapa bentuk komunikasi nonverbal statis adalah sebagai berikut. (1) Postur Fisik, (2) Daya Tarik wajah (3) pakaian dan aksesoris. Konteks situasi mengacu pada gagasan kondisi secara umum dimana bahasa pengucapan itu terjadi. Peran "konteks situasi" untuk menentukan makna dalam penggunaan bahasa. Konteks mencakup konteks situasi mengenai faktor linguistik dan konteks situasi mengenai faktorfaktor nonlinguistik. Rahardi (2009: 21) menegaskan bahwa konteks yang dimaksud dapat mencakup dua macam hal, yaitu konteks yang bersifat sosial dan konteks yang bersifat sosietal. Konteks tersebut meliputi: (1) Konteks situasi bukan hanya latar belakang untuk katakata pada saat tertentu, melainkan mencakup etnis budaya Jawa yang berkaitan. Konteks situasi mencakup faktor linguistik dan faktor nonlinguistik.

Faktor linguistik yaitu konteks atau ko-teks merupakan kalimat yang biasanya mendahului dan mengikuti kalimat atau elemen bahasa lainnya, sedangkan faktor nonlinguitik yaitu konteks yang mengacu pada beberapa cara selain penggunaan kata-kata yaitu kontak mata, gerakan anggota badan seperti ekspresi wajah, gerakan mata, gerakan kepala, gerakan tangan, gerakan badan, atau kombinasi yang satu dengan yang lain; (2) Konteks sosial dan budaya adalah hal-hal yang timbul sebagai akibat dari 
munculnya interaksi antaranggota masyarakat dalam budaya tertentu; dan (3) Konteks sosietal adalah hal-hal yang menjadi faktor penentunya adalah kedudukan (rank) dari anggota masyarakat dalam institusiinstitusi sosial yang ada di dalam masyarakat sosial dan budaya tertentu. Hal ini menunjukkan bahwa munculnya konteks sosietal adalah adanya kekuasaan.

Pesan-pesan nonverbal merupakan kompetensi komunikasi yang diungkapkan secara langsung dan mengonstruksi makna pragmatik. Kompetensi komunikasi yang berkaitan dengan komunikasi nonverbal berkaitan dengan kompetensi encoding dan kompetensi decoding (Puccinelli, 2008). Encoding adalah kegiatan yang berkaitan dengan pemilihan lambang-lambang yang akan digunakan dalam kegiatan berkomunikasi oleh penutur sedangkan decoding adalah kegiatan dalam berkomunikasi yang dilaksanakan oleh mitra tutur (Eriyanti, 2017:79). Dengan demikian, jenis-jenis kompetensi di atas merujuk pada kegiatan tuturan antara penutur dan mitra tutur.

Penutur menggunakan kompetensi untuk menyampaikan pesan komunikasi dan makna pragmatik sesuai dengan pikirannya. Mitra tutur menggunakan kompetensi untuk memahami dengan baik pesan komunikasi dan makna pragmatik dari penutur. Baik bahasa Jepang maupun bahasa Indonesia mempunyai jenis kalimat imperatif masing-masing dari penggunaan fungsi yang digunakan sama. Sebagai bahasa sumber dan bahasa target, selain itu dalam penyampaiannya membutuhkan komunikasi nonverbal sebagai penjelas maksud dari kalimat imperatif tersebut. Adapun beberapa fungsi kalimat imperatif, sebagai berikut.

\section{Fungsi Perintah}

Dalam bahasa Indonesia fungsi imperatif perintah ditandai dengan partikel -lah. Sedangkan dalam bahasa Jepang menurut Nitta (1991 : 230) bentuk fungsi perintah 動詞十なさ い,動詞〜ろ dan 動詞〜て. Fungsi imperatif perintah berkisar antara imperatif yang sangat halus sampai dengan imperatif yang sangat kasar. Hasil tindakan yang menguntungkan untuk penutur maka akan menjadi beban untuk lawan tutur (Roni, 2005: 80). Dalam fungsi ini, pilihan lawan tutur untuk tidak melakukan perintah dari penutur sangat kecil.

(1) しばらく静かにやすみなさい。

a 'Sementara istirahatlah dengan tenang.' (Nitta, 1991:230)

b Dik, tolong tenang sebentar! (wulandari, 2017:15)

Konteks tindak tutur (1a) dituturkan oleh kepala manajer disebuah restoran pada saat jam istirahat kepada salah satu pelayan. Kepala manajer tersebut melihat kondisi restoran yang sangat ramai, tetapi salah satu pelayannya terlihat sangat kelelahan. Kemudian Kepala Manajer tersebut mengucapkan tuturan tersebut dengan menggunakan perintah yang lebih sopan. Bentuk perintah ini terkesan tegas, dan memaksa. Sedangkan 1b dituturkan oleh seorang kakak dirumah yang mendengar adiknya menangis dengan suara kencang. Tuturan diatas diucapkan dengan intonasi tinggi, sehingga membuat lawan tutur merasa sangat terbebani untuk melakukan tindakan yang diinginkan oleh penutur

\section{Fungsi Permintaan}

Fungsi imperatif permintaan adalah kalimat imperatif dengan kadar suruhan yang sangat halus. Biasanya disertai dengan sikap penutur lebih rendah dibandingkan dengan penutur pada waktu menuturkan imperatif perintah. Dalam Bahasa Indonesia fungdi permintaan ditantadai dengan ungkapan tolong, mohon, dan beberapa ungkapan lainnya seperti sudilah kiranya, dapatkah seandainya, diminta dengan hormat, dan dimohon dengan sangat. Sedangkan dalam bahasa Jepang menurut Nitta 動詞〜ください,お十動 詞十ください. Fungsi ini memliki manfaat bagi penutur, yakni ada kemungkinan lawan tutur terbebani, sehingga lawan tutur memiliki pilihan untuk tidak melakukan. Sejalan dengan itu pada fungsi permintaan hasil tindakan penutur menguntungkan untuk lawan tutur. (Roni, 2005 : 80). Sehingga bentuk imperatif langsung yang digunakan adalah imperatif bentuk sopan.

$$
\begin{aligned}
& \text { (2) いいから、話してください } \\
& \text { a "karena baik, tolong } \\
& \text { bicaralah" (Nitta, 1991:230) } \\
& \text { b Tolong beritahu saya besok jika ada } \\
& \text { kuliah (Roni, } 2005 \text { : 80) }
\end{aligned}
$$

Konteks tindak tutur 2a dituturkan guru kepada seorang murid ketika berada di dalam 
kelas, dia ingin menasehati Kentaro teman sekelasnya untuk tidak berbuat kenakalan di sekolah. Konteks tindak tutur $2 \mathrm{~b}$ dituturkan seorang ibu yang meminta anaknya untuk mengambilkan tasnya. Permintaan ini terkesan halus dan sopan, sehingga permintaan yang diucapkan memiliki kesan tidak memaksa.

\section{Fungsi Permohonan}

Fungsi permohonan sebenarnya hampir sama dengan fungsi permintaan, tetapi fungsi permohonan ini terkesan halus dibandingkan dengan fungsi permohonan. Karena biasanya penutur berkedudukan lebih rendah dibandingkan dengan lawan tutur. (Roni, 2005: 84). Fungsi ini memberikan pilihan lawan tutur untuk melakukan sesuatu tindakan sangat kecil. Dalam bahasa Indonesia, imperatif langsung ini ditandai dengan kata mohon. Sedangkan dalam bahasa Jepang ditunjukkan denan bentuk imperatif langsung 動詞〜て十ください.

\section{（3）館長にお話しください \\ a "silahkan berbicara dengan direktur" \\ b Bu irawati, silahkan duduk disini!}

Konteks tuturan 3a diucapkan oleh pegawai resepsionis kepada tamu direktur. Tuturan merupakan tindak tutur imperatif langsung yang memiliki bentuk お + 動詞 + ください merupakan bentuk permohonan, yang terkesan lebih halus dan sopan, sehingga permohonan yang diucapkan memiliki kesan tidak memaksa lawan tutur.

\section{Fungsi Larangan}

Fungsi imperatif larangan adalah perintah kepada lawan tutur agar tudak melakukan suatu tindakan. Dalam bahasa Indonesia bentuk fungsi imperatif larangan ditandai dengan pemakaian kata jangan. Sedangkan dalam bahasa Jepang menurut Nitta (1991 : 233) 動詞 動詞〜ないでください,動詞〜ないでくれ dan 〜な.
（4）行かないでください
a "tolong jangan pergi"
(Fanani, 2011:48)
b この電話を使うな。
Jangan angkat telepon ini. (shindu, 2021: 2)
c Jangan merokok! (wulandari, 2017: 16)

Tuturan 4a menunjukkan bentuk imperatif langsung fungsi larangan, dilihat dari 行かない でください Bentuk imperatif langsung dengan tanda 動詞〜ないでください yang berarti "tolong jangan". Bentuk imperatif langsung ini terkesan lebih sopan dan formal dibandingkan dengan 動詞〜な yang terkesan non formal dan santai. Biasanya digunakan pada atasan dan bawahan, orang tua kepada anaknya, atau orang yang baru dikenal.

\section{Fungsi Ajakan}

Fungsi imperatif ajakan adalah perintah yang akhirnya dilaksanakan lawan tutur bersama penutur. Fungsi imperatif ajakan lawan tutur harus mengerjakan tindakan yang disampaikan oleh penutur. (Roni 2005: 86) Dengan demikian, penutur mendapat keuntungan yang besar sedangkan lawan tutur mendapatkan beban untuk melakukan tuturan penutur. Dalam bahasa Indonesia, bentuk imperatif ajakan ini ditandai dengan ayo, biar, coba, mari, harap, hendaknya dan hendaklah. Sedangkan dalam bahasa Jepang menurut Nitta (1991:261) bentuk imperatif ajakan yaitu 動詞〜ましょう, 動詞〜 ないか／動詞〜ませんか dan 動詞〜おう／よ $\zeta$ selain itu menurut pendapat Fanani bentuk imperatif langsung ajakan yakni 動詞〜おう/よ う.

（5）皆さん、元気よく走りましょう

a "semuanya, ayo kita berjalan dengan riang"

Ayo kita kobarkan semangat juang!

b (wulandari, 2017: 18)

食べろ

c "ayo makan" (svhan, 2016)

Konteks tuturan 5 a dituturkan oleh seorang guru yang sedang bertamasya dengan muridmuridya. Selanjutnya tuturan $5 \mathrm{~b}$ ditututkan oleh pemimpin pasukan dimedan perang untuk mengajak para pasukannya untuk lebih semangat berjuang. Tuturan $5 \mathrm{c}$ dituturkan oleh seorang ayah kepada anaknya mengajak makan dengan cepat.

\section{METODE}

Dalam penelitian ini menggunakan metode deskriptif kotransitif yang meliputi pengumpulan data, analisis data, dan perbandingan hasil analisis data atau dengan 
sebutan lain yaitu analisis kontransitif, yaitu metode sinkronis pada analisis bahasa untuk menunjukkan perbedaan dan persamaan antara bahasa atau dialek guna mencaru irinsip yang dapat dijabarkan dalam masalah praktis. (Kridalaksana, 1982: 11)

Metode deskriptif yaitu metode yang memiliki tujuan untuk membuat gambaran dengan mendeskripsikan, secara sistematis, factual, dan akurat mengenai data-data, sifatsifat, serta hubungan antar fenomena yang ditelliti (Djajasudarma, 1993:8). Metode deskriptif mampu mendeskripsi data secara alamiah. Penelitia metode deskriptif dilakukan berdasarkan fakta atau fenomena secara empiris yang ada pada peuturnya.

Perbandingan antara dua bahasa dapat dilakukan dengan dua cara, yaitu perbandingan historis dan perbandingan deskriptif. Penelitian ini dilakukan dengan cara yang kedua. Perbandingan deskriptif pada dasarnya mengamati kemiripan atau perbdaan unsur kebahasaan terteu pada dua bahasa yang berkerabat atau tidak berkerabat.

Analisis dilakukan secara terpisah dimana bahasa Jepang dan bahasa Indonesia diamati dari sudut pandang pendekatan masing-masing bahasa lalu dibandingkan menjadi ciri khas masing-masing bahasa. Selanjutnya metode analisis kontrastif digunakan untuk membandingkan perbandingan antara bahasa Jepang dan bahasa Indonesia yang menghasilkan sejumlah fakta berupa persamaan dan perbedaan antara komunikasi verbal yang memperkuat komunikasi verbal bahasa Jepang dan bahasa Indonesia.

Data merupakan bahan penelitian, bahan yang dimaksud merupakan bahan jadi. Dari bahan itulah diharapkan objek penelitian dapat dijelaskan, karena didalam bahan tersebut terdapat objek penelitian yang dimaksud (Sudaryanto, 1981:22). Sumber data tertulis bahasa Jepang adalah drama Jepang Hanbun Aoi. Hal ini akan dilakukan dengan pertimbangan bahwa, pertama; drama tersebut dapat memberikan informasi bentuk komunikasi non verbal yang jumlahnya memadai, kedua; drama yang ditentukan sebagai sumber data itu tentu saja memuat berbagai bentuk komunikasi nonverbal bahasa Jepang sebagai inti dari penelitian ini.

Data dalam penelitian ini adalah berupa bentuk komunikasi nonverbal yang sudah ada baik dalam bahasa Jepang maupun bahasa Indonesia. Data yang diperoleh dengan metode simak akan dilanjutkan dengan metode teknik catat. Penulis menyimak beberapa episode drama bahasa Jepang dan sinetron Indonesia. Teknik lanjutannya adalah teknik catat, penulis mencatat semua data yang diperoleh dalam kartu data. Data bahasa Jepang brupa drama Hanbun Aoi dengan 20 episode, dengan cara pemerolehan data yang telah dicatat dalam kartu data kemudian dialnalisis berdasarkan teori- teori yang relevan. Selanjutnya data dianalisis dengan metode deskriptif kontransitif, kemudian dijabarkan, dibandingkan antara komunikasi nonverbal bahasa Jepang dan bahasa Indonesi untuk menenmukan prinsip mendasar dari persamaan dan perbedaan dalam penggunaannya.

\section{HASIL DAN PEMBAHASAN}

Hasil penelitian ini ini disajikan temuan hasil kajian, baik hasil penelitian bentuk komunikasi nonverbal dalam tuturan imperatif. Setelah penyajian, artikel ini kemudian mengulas dalam bentuk pembahasan secara bertutru-turut sebagai berikut.

\section{Wujud Komunikasi Nonverbal}

Wujud komunikasi nonverbal ada dua yaitu komunikasi nonverbal dinamis dan komunikasi nonverbal statis. Wujud bahasa nonverbal dibagi menjadi tiga bagian utama yaitu gestur, ekspresi wajah, kontak mata. Sedangkan bahasa nonverbal statis yaitu postur fisik dan aksesoris. Pertama, peneliti akan menganilis data dari drama Jepang yang berjudul Hanbun Aoi dengan pengambilan data dari beberapa episode acak.

\section{Wujud Komunikasi Non-verbal Dinamis}

Pemakaian komunikasi nonverbal selalu dikaitkan dengan konteks pemakaian bahasa lisan dalam kehidupan bermasyarakat. Misalnya, ketika seseorang bertutur "apabila menurutmu itu baik, silahkan lakukan!" (konteks: penutur sambil memalingkan wajah). Komunikasi nonverbal yang digunakan oleh penutur itu adalah "memalingkan wajah", mitra tutur menangkap makna pragmatik penutur tidaksetuju dengan maksud lawan tutur. 


\section{Gestur pada Tuturan Imperatif bahasa Jepang}

\section{a. Getsur pada bagian kepala}

Gestur merupakan wujud komunkasi komunikasi nonverbal yang melihatkan gerakan pada kepala, tangan dan anggota tubuh. Beragam gesture pada bagian kepala muncul ketika penutur dan mitra tutur saling berkomunkasi.

Data 1

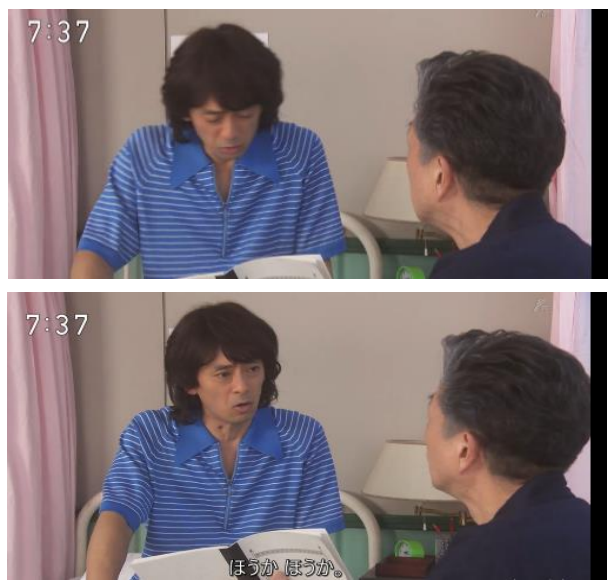

1. Wujud : anggukan penutur

2. Tuturan：人の話 聞いてよ！

“dengarkan orang berbicara!" (HA03, 08:0508:11)

3. Keterangan : Penutur mengangguk ketika memerintah kepada lawan tutur. Gerakan anggukan terkesan lebih komunikatif, artinya perintah tuturan imperatif secara verbal mendapatkan penekanan pada kata tuturan imperatif perintah bentuk $\lceil\sim \tau\rfloor$. Penutur diuntungkan lawan tutur terbebani harus melakukan keinginan penutur

1. Kompetensi : kompetensi encoding, yaitu pemilihan gesture anggukan sebagai wujud komunikasi nonverbal yang mengiri komunikasi tuturan imperatif secara verbal.

2. Konteks : Konteks linguistik yang ada pada tuturan tersebut adalah interaksi sehari-hari antara ayah dan anak, penutur berusaha memberikan perintah dengan penekanan agar disimak dengan baik oleh lawan tutur.
Data 2

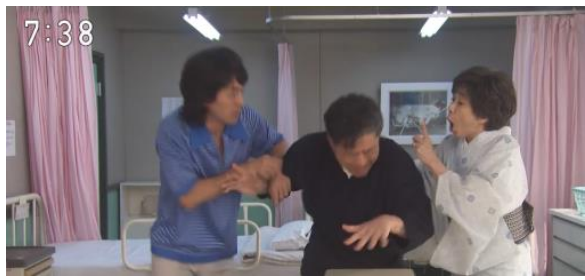

1. Wujud : anggukan penutur

2. Tuturan：やめろ！ここは病院...!

"ayo hentikan! Disini rumah sakit!"

$$
\text { (HA03, 09:01-09:07) }
$$

3. Keterangan : Penutur mengangguk ketika memerintah kepada lawan tutur. Gerakan anggukan terkesan lebih komunikatif, artinya perintah tuturan imperatif secara verbal mendapatkan penekanan pada bentuk tuturan imperatif fungsi ajakan $\lceil\sim 弓\rfloor$.

Kondisi lawan tutur tutur terbebani dengan permintaan penutur yang harus dilakukan

4. Kompetensi : kompetensi encoding, yaitu pemilihan gesture anggukan sebagai wujud komunikasi nonverbal yang mengiringi komunikasi tuturan imperatif secara verbal.

5. Konteks : Konteks linguistik yang ada pada tuturan tersebut adalah interaksi sehari-hari antara ayah dan keluarganya, penutur berusaha memberikan perintah dengan penekanan komunikasi nonverbal agar disimak dengan baik oleh lawan tutur.

Data 3
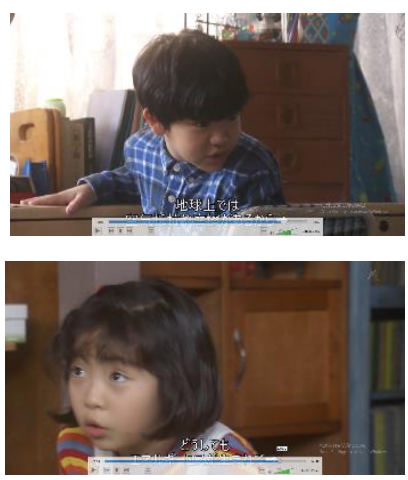

1. Wujud : anggukan penutur

2. Tuturan: 津 : 今のはないしょにしてく

れ! 


\author{
"Rahasiakan sekarang!" \\ 鈴女：了解致した。 \\ "saya mengerti"
}

(HA04, 13:32-13:35)

3. Keterangan : Penutur membalikkan kepala dan mengangguk ketika memerintah kepada lawan tutur. Gerakan anggukan terkesan lebih komunikatif, artinya perintah tuturan imperatif secara verbal mendapatkan penekanan pada bentuk kalimat imperatif fungsi perintah $「 \sim し て く れ 」$. Kondisi penutur diuntungkan karena lawan tutur tutur terbebani harus melakukan perintah tersebut.

4. Kompetensi : kompetensi encoding

5. Konteks : Konteks linguistik yang ada pada tuturan tersebut adalah interaksi sehari-hari antara sesame teman, peutur dan lawan tutur lebih menggunakan bahasa nonformal karena mereka berteman dekat, penutur berusaha memberikan perintah dengan penekanan komunikasi nonverbal agar disimak dengan baik oleh lawan tutur. Oleh karena itu mendapatkan respon dari lawan tutur seperti anggukan

\section{Data 4}
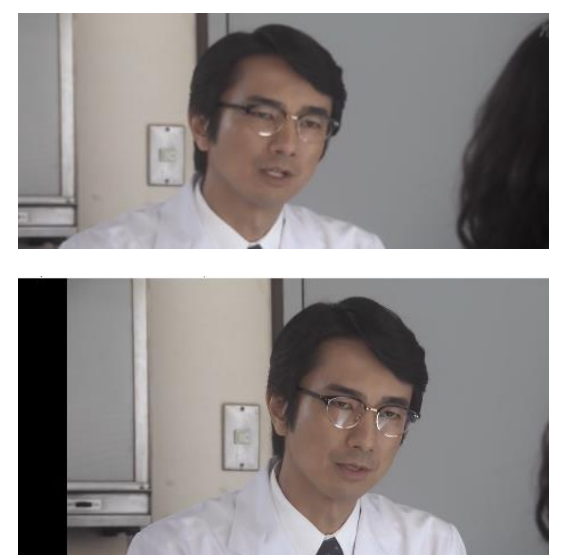

1. Wujud : anggukan penutur

2. Tuturan:

$$
\begin{aligned}
& \text { 先生 } \text { : まず担任の先生におっしやって } \\
& \text { 下さい。後ろの方の席では聞こえ } \\
& \text { にくいしどこから音がしているの }
\end{aligned}
$$

$$
\text { か判別するのが.... }
$$

"Pertama-tama, tolong beritahu wali kelas Anda. Sulit untuk mendengar di kursi belakang, dan itu adalah untuk menentukan dari mana suara itu berasal....!"

$$
\text { (HA10, 05:19-05:26) }
$$

3. Keterangan : Penutur mengangguk ketika menjelaskan dan meminta tolong kepada lawan tutur. Gerakan anggukan terkesan lebih komunikatif, artinya perintah tuturan imperatif secara verbal mendapatkan penekanan pada bentuk kalimat imperatif fungsi permohonan「お十動詞 + くださ い」. Lawan tutur diuntungkan karena tidak harus melakukan perintah yang disampaikan oleh penutur

\section{Kompetensi : kompetensi encoding}

5. Konteks : Konteks linguistik yang ada pada tuturan tersebut adalah interaksi formal antara dokter dan wali pasien, penutur dan lawan tutur menggunakan bahasa formal karena mereka tidak saling mengenal, penutur berusaha memberikan perintah dengan penekanan komunikasi nonverbal agar disimak dengan baik oleh lawan tutur.

Pada beberapa data diatas gestur mengangguk adalah gesture kepala yang naik turun sebagai bentuk persetujuan atau pemahaman ketika menyimak sesuatu (givens, 2015: 68). Tetapi gesture anggukan yang disampaikan penutur melalui tuturan imperatif memiliki peran lain. Anggukan tidak hanya diartikan sebagai bentuk memahami atau menyutujui suatuhal, namun kebiasaan mengangguk sangat erat terkait dengan interaksi penutur dan lawan tutur ynga berlatar belakang budaya Jepang. Kebiasaan tersebut menjadi sebuah ungkapan kultural yang unik. (Burgoon, 2010: 32) Ungkapan unik termasuk sebagai gerakan yang ikonis, yakni gerakan yang berfokus kepada tuturan tertentu, seperti anggukan (McNeill,2000). Sehingga pemahaman suatu kultural untuk memahami sebuah penggunaan kebiasaan komunikasi nonverbal dan mencoba untuk menggunakannya dalam komunikasi dengan pemahaman kultur itu sendiri (matsumoto, 2013:98). Dengan demikian Gestur anggunkan dalam komunikasi nonverbal seseorang menggangguk tidak untuk menyetujui melainkan juga bentuk unik dari 
penutur dan lawan tutur berdasarkan latar belakang kebudayaannya. Gestur mengangguk dalam masyarakat Jepang tidak dapat dipaai pada satu sudut pandang sebagai bentuk persetujuan atau pehaman. Gestur mengangguk menjadi sebuah cerminan budaya Jepang.

\section{b. Getsur pada bagian Tubuh pada Bahasa Jepang}

Gestur bagain tubuh ditunjukkan dalam komunikasi nonverbal dalam gerakan tangan, lengan, siku, kaki, pundak, perut, dan gesture tubuh lainnya. Bentuk bahasa dalam tuturan imperatif ditunjukkan oleh gesture tangan dalam beberapa situasi seperti saat memberikan peghargaan menunjukkan gestur ibu jari, dengan menggerakan telunjuk ketika memerintah seseorang untuk melakukan sesuatu. Peneliti menemukan dalam drama bahasa Jepang sebagai berikut.

\section{Data 5}

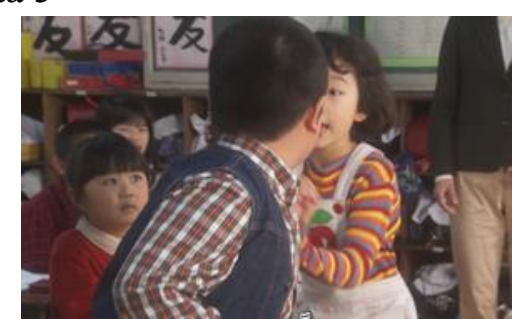

1. Wujud : telapak tangan

2. Keterangan : gerakan telapak tangan penutur mendorong lawan tutur dilakukan untuk memerintah lawan tutur dengan keras untuk keluar dari ruangan tersebut. Gerakan anggukan terkesan lebih komunikatif, artinya tuturan imperatif fungsi perintah tersebut secara verbal dalam bentuk kalimat 「〜れ」 mendapatkan penekanan kontak mata juga yang menyertai tuturan verbal imperatif . Penutur mendapatkan keuntungan sedangkan lawan tutur terbebani karena lawan tutur harus melakukan keinginan penutur

3. Tuturan :

$$
\begin{aligned}
\text { 鈴女 ： 悪役レスラーがい } \\
\text { たのです。帰れ! } \\
\text { 帰れ! }
\end{aligned}
$$

(HA4, 01:49-01:52)

\section{Kompetensi : kompetensi encoding}

5. Konteks : Konteks linguistik yang ada pada tuturan tersebut adalah interaksi non formal antara sesama teman, penutur dan lawan tutur menggunakan bahasa formal karena mereka tidak saling mengenal, penutur berusaha memberikan perintah dengan keras serta mengunakan penekanan komunikasi nonverbal agar disimak dengan baik oleh lawan tutur.

Gestur tangan pada data diatas meunjukkan penutur menggerakan telapak tangannya untuk mendorong memberikan perlawanan kepada lawan tuturnya yang memilai perkelahian dengan tuturan imperatif memerintahkan pulang. Gestur tersebut muncul tepat bersamaan dengan kata "pulanglah! Pulanglah", sehingga gestur mempertegas tuturan verbal tersebut. Peran Ilustrator berjenis kinetograf yaitu menampilkan tindakan bahasa melalui anggota tubuh (Burgoon 2016: 127). Penutur mengungkapkan pesan komunikasi (encoding) verbal melalui tuturan imperatif perintas dengan komunikasi nonverbal yang menunjukkan kesan negatif dalam perkelahian tersebut. Dengan demikian, gestur telapak tangan yang dicipakan disebut sebagai gestur yang mengilustrasikan tuturan penutur. Ilustrai tuturan verbal imperatif perintah dipertegas dengan komunikasi nonverbal.

\section{Ekspresi Wajah}

Bentuk komunikasi nonverbal ekspresi wajah adalah wujud komunikasi nonverbal yang menampilkan emosi penutur dan lawan tutur dalam interaksi komunikasi. Emosi yang ada dalam suatu interaksi memberikan dampak kepada penutur dan lawan tutur untuk mengungkapkan situasi yang dimiliki. Ekspresi wajah dapat diamati melalui gerak birbir ketika bertutur kata atau menyimak tuturan, seperti pada data berikut.

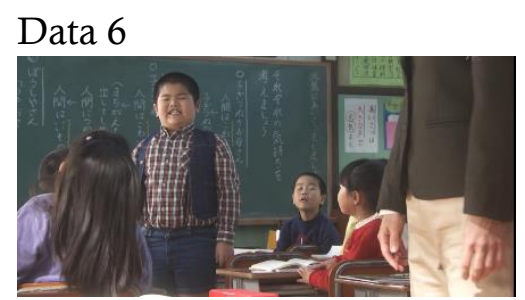


1. Wujud : ekspresi tersenyum

2. Keterangan : Ekspresi senyuman yang terjadi ketika seorang penutur yaitu siswa meminta tolong kepada ibu guru dengan bentuk kalimat imperatif fungsi meminta $\quad(\sim \tau<$ ださい). Penutur merasa perkataannya humoris, tuturan perintahnya disampaikan dengan humor. Penutur memberikan keuntungan kepada lawan tutur karena permintaan tersebut terkesan sopan dan lawan tutur tidak harus melakukan permintaan tersebut.

3. Tuturan :

龍之介 : 先生カラスの相手はいいんで、 授業進めて下さい!あっ 違った ネズミの相手！あっそれも違う スズメか！

"bu guru, pasangan gagak itu baik, jadi. Tolong lanjutkan pelajarannya. $\mathrm{Oh}$

bukan, pasangan tikus, oh itu juga

bukan, apa suzume?"

(HA4, 01:26-01:39)

4. Kompetensi : kompetensi encoding, yaitu

pemilihan ekspresi senyuman

yang menyertai pesan tuturan

verbal.

5. Konteks : konteks situasional, yakni interaksi komunikaSI didalam kelas, penutur memberikan gurauan ditengah pembelajaran. Konteks situasional meruuk pada situasi humor yang diciptakan penutur melalui ekspresi senyumannya. Gerakan bibir yang digunakan oleh Ryunosuke sebagai seorang murid.

Data diatas menunjukkan seseorang penutur tersenyum saat memberikan perintah kepada lawan tutur. Penutur merasa bahwa tuturan yang disampaikan mengandung humor yang akan berdampak pada situasi interaksi komunikasi yang humoris. Ekspresi senyuman tersebut yakni syntactic display. Ekspresi yang menyertai tuturan verbal dan menjadi penanda penda tuturan bverbal penutur (Burgoon, 2016). Dengan demikian ekspresi wajah menjadi penanda tuturan imperatif dengan fungsi permintaan menjadi penanda dan penegas terhadap tuturan verbalnya. Hal tersebut dibuktikan dengan ekspresi senyuman terjadi tepat setalah tuturan imperatif yang disampaikan selesai diucapkan. Dengan demikian ekspresi senyuman yang diungkapkan penutur merupakan ilustrasi tuturna yang mengilustrasikan tuturan imperatif permintaan dengan ekspresi sehingga maksud penutur sampai kepada lawan tutur. Penutur mengkofing tuturan imperatifnya disertai dengan ekspresi tersenyum merupakan tindakan bahasa yang menciptakan situasi interaksi pembelajaran dikelas menjadi humoris.

\section{Wujud Komunikasi Nonverbal Statis}

Bahasa nonverbal satstis merupakan bentuk komunikasi nonverbal yang melekat pada fisik baik penutur maupun lawan tutur. Dalam latar belakang budaya seperti budaya Jepang, bahasa nonverbal statis mendapatkan perhatian. Kebiasaan orang Jepang melihat seseorang berdasarkan tampilan fisik seorang ayah yang menggunakan Hakama (baju Tradisional Jepang). Ketika seseorang menggunakan Hakama mencerminkan wibawa yang tinggi, karena Hakama merupakan salah satu baju tradisional Jepang yang digunakan para samurai legendaris. Pengklasifikasian bentuk komunikasi nonverbal statis, meliputi postur, bentuk hidung, bentuk mata, dan aksesoris.

\section{Pakaian}

Seseorang menggunakan pakaian dalam situasi yang formal atau santai terutama ketika dalam situasi formal didalam kelas seorang guru mengajar dikelas menggunakan pakaian firmal, menampilkan hal yang rapi. Sudut pandang masyarakat Jepang adalah menilai seorang secara visual dalam memakai pakaian, seperti berikut ini. 
Data 7
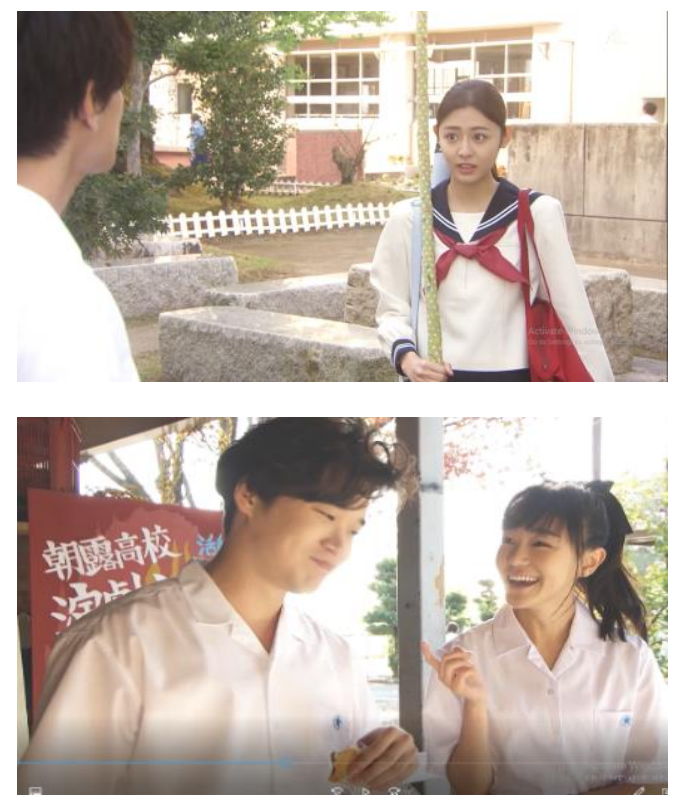

1. Wujud : Pakaian Formal

2. Keterangan : Pakaian formal merupakan pakaian yang cocok digunakan untuk bertatap muka dengan siswa lain. Pakaian formal termasuk dalam istilah clothing consciousness merujuk pada kecermatan dalam pemilihan pakaian yang tepat

3. Konteks : interaksi pembelajaran di dalam kelas. Konteks situasional, penutur sedang berdiri dengan sikap santai saat berbicara dengan lawan tutur.

\section{Data 8}

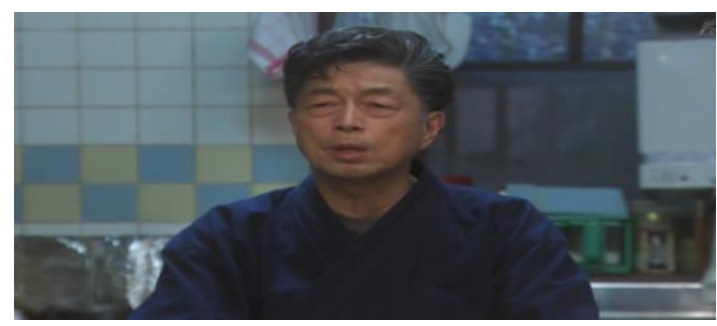

1. Wujud: Pakaian Tradisiolnal

2. Keterangan : Pakaian Tradisional merupakan pakaian yang cocok digunakan untuk berkomunikasi dilingkungan keluarga yang masih melestarikan budaya. Pakaian tradisional termasuk pada istilah clothing consciousness merujuk pada kecermatan dalam pemilihan pakaian yang tepat.

3. Konteks : interaksi komunikasi di dalam keluarga tepatnya di meja makan. Konteks situasional, penutur sedang duduk dan berbicara santai dengan lawan tutur.

Pakaian merupakan wujud bahasa nonverbal statis yang lebih menggambarkan seseorang baik laki-laki maupun perempuan yang terdapat dalam interaksi komunikasi. Pada data ke 8 adalah kedua siswi tersebut menggunakan seragam terutama ketika berada dilingkungan situasi formal yaitu sekolah, namun bentuk seragam mereka berbeda sesuai dengan identitas sekolah masing-masing hal tersebut bertujuan untuk menampilkan karakteristik salah satu bagian yang dinilai masyarakat Jepang. Sedangkan pada data ke 9 adalah seorang kake menggunakan Hakama (baju tradisional Jepang) ditengah meja makan bersama keluarga besar, penggunaan Hakama ini dinilai dengan menunjukkan wibawa yang tinggi karena hakama dulu digunakan oleh para samurai legendaris, Hal tersebut bertujuan untuk menampilkan karakteristik salah satu bagian yang dinilai oleh budaya Jepang.

\section{Bentuk Komunikasi nonverbal dinamis dalam Bahasa Indonesia}

Komunikasi nonverbal dinamis juga ditemukan dalam interaksi komunikasi bahasa Indonesia yang diambil dari sinteron Ikatan Cinta, pengambil data diambil secara random dari berbagai episode. Kemudian akan ditampilkan melalui wujud komunikasi bahasa nonverbal sebagai berikut ini.

\section{Gesture}

\section{a. Gerakan Kepala}
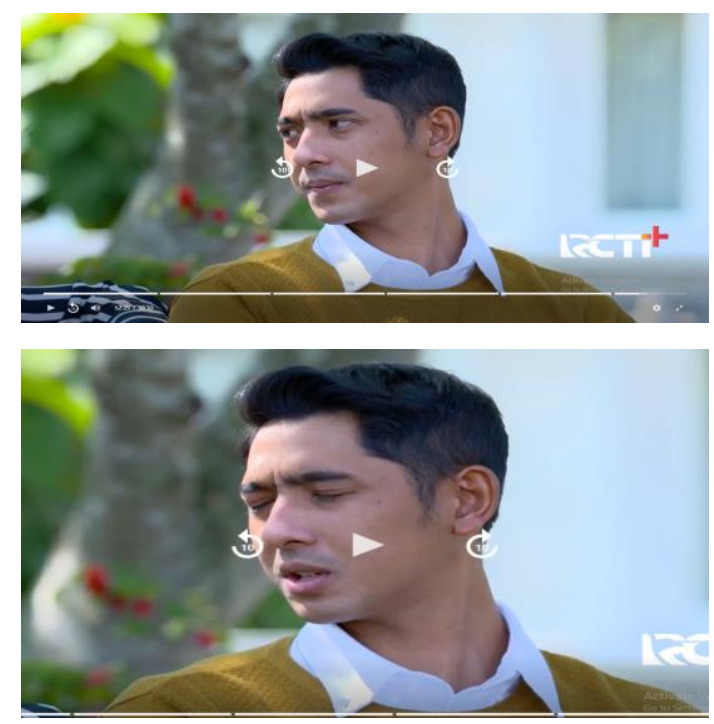
Data 9

1. Wujud : anggukan penutur

2. Tuturan : "tolong nurut sama suami! Tunggu sampai kandungan kamu lebih kuat baru boleh bekerja"

(IC294, 52:53-52:60)

3. Keterangan : Penutur mengangguk ketika memerintah kepada lawan tutur. Gerakan anggukan terkesan lebih komunikatif, artinya perintah tuturan imperatif secara verbal mendapatkan penekanan pada bentuk tuturan imperatif fungsi perintah tolong. Fungsi perintah ini menguntung penutur karena lawan tutur harus melakukan keinginan penutur

4. Kompetensi : kompetensi encoding, yaitu pemilihan gesture anggukan sebagai wujud komunikasi nonverbal yang mengiringi komunikasi tuturan imperatif secara verbal.

5. Konteks : Konteks linguistik yang ada pada tuturan tersebut adalah interaksi sehari-hari antara suami dan istri, penutur berusaha memberikan perintah dengan penekanan komunikasi nonverbal agar disimak dengan baik oleh lawan tutur.

Pada tuturan imperatif diatas digunakana anggukan yang menunjukkan arti untuk digunakan memberikan interaksi tidak menyetujui lawan tutur untuk melakukan sesuatu, sehingga penutur memberikan penekanan untuk melembutkan tuturan perintah yang disampaikan kepada lawan tutur.

\section{b. Gestur gerakan tangan}

Data 10

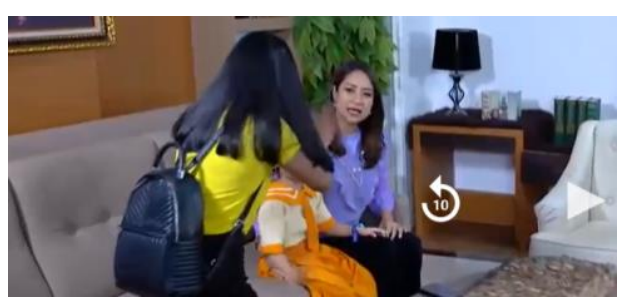

1. Wujud : telapak tangan

2. Tuturan : "belajar yah, jangan main!" (IC323, 05:40-05:42)

3. Keterangan : gerakan telapak tangan penutur menepuk pundak lawan tutur untuk memberikan larangan kepada lawan tutur dengan lembut ketika berpamitan akan dari rumah. Gerakan telapak tangan terkesan lebih komunikatif, artinya berfungsi larangan tersebut disertai juga dengan tuturan imperative fungsi larangan, lawan tutur merasa terbebani dengan larangan penutur sehingga harus melakukan keinginan penutur

4. Kompetensi : kompetensi encoding, yaitu penyampaian pesan tuturan verbal dengan gerakan telapak tangan

5. Konteks : Konteks linguistik yang ada pada tuturan tersebut adalah interaksi informal antara ibu dan anak, penutur dan lawan tutur menggunakan bahasa informal karena mereka memiliki hubungan dekat, penutur berusaha memberikan larangan dengan penekanan komunikasi nonverbal agar disimak dengan baik oleh lawan tutur.

Data 11

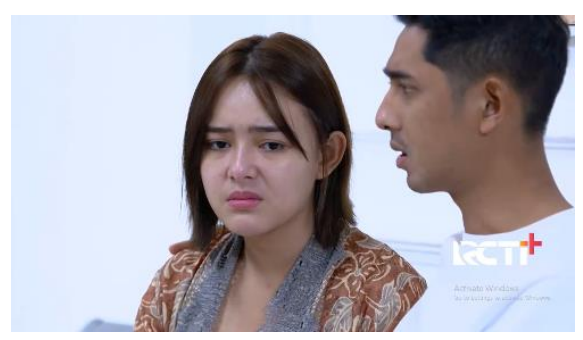

1. Wujud : telapak tangan

2. Keterangan : gerakan telapak tangan penutur menepuk pundak lawan tutur untuk memberikan larangan kepada lawan tutur dengan lembut.

3. Tuturan: "jangan menyalahkan diri sendiri, saya yakin elsa baik-baik saja!" (IC310, 29:57-29:60)

4. Kompetensi : kompetensi encoding, yaitu penyampaian pesan tuturan verbal dengan gerakan telapak tangan. Tuturan tersebut merupakan tuturan imperative berfungsi larangan, penutur mendapat keuntungan sedangkan lawan tutur mendapatkan beban untuk melakukan sesuatu yang diinginkan

5. Konteks : Konteks situasional sebagai seorang suami yang berusaha menenangkan emosi istri, penutur berusaha memberikan larangan dengan penekanan komunikasi 
nonverbal agar disimak dengan baik oleh lawan tutur.

Data 12

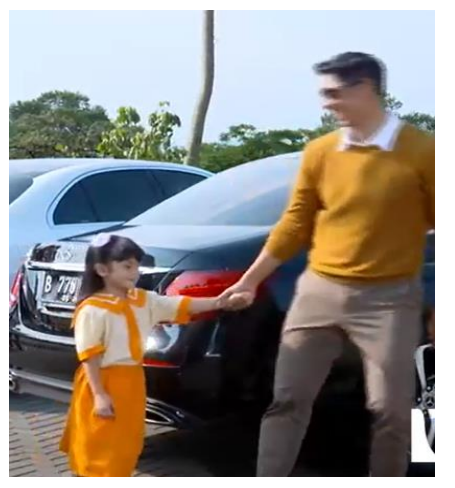

1. Wujud : telapak tangan

2. Tuturan : "Ayo rena ikut papa, papa punya kejutan buat rena!"

(IC294, 04:55-05:05)

3. Keterangan : gerakan telapak tangan penutur menggandeng lawan tutur untuk mengajak lawan tutur pergi kesuatu tempat. Tuturan imperative yang digunakan berfungsi mengajak dimana penutur diuntungkan dengan memberikan beban kepada lawan tutur untuk melakukan keinginannya

4. Kompetensi : kompetensi encoding, yaitu penyampaian pesan tuturan verbal dengan gerakan telapak tangan

5. Konteks : Konteks linguistik yang ada penutur dan lawan tutur menggunakan bahasa informal karena mereka memiliki hubungan dekat sebagai ayah dan anak, penutur berusaha memberikan ajakan dengan penekanan komunikasi nonverbal agar disimak dengan baik oleh lawan tutur.

Pada beberapa tuturan diatas terdapat komunikasi nonverbal gestur gerakan tangan yang menunjukkan penekanan maksud dari tuturan imperatid yang disampailan. Dimana tuturan tersebut muncul tepat bersamaan dengan tuturan imperatif, dengan peran illustrator berjenis kinetograf, selanjutnya dengan encoding verbal melalui tuturan imperatif dengan komunikasi nonverbal yang ditunjukkan dengan kesan positif. Penelitian ini merupakan sebagian kecil dari bentuk komunikasi nonverbal pada kalimat imperatif, untuk selanjutnya semoga diharapkan dapat dikembangkan oleh peneliti yang lain.

\section{SIMPULAN}

Berdasarkan hasil penelitian untuk rumusan masalah yang pertama, dapat diketahui bahwa bentuk komunikasi nonverbal yang ditemukan pada komunikasi nonverbal pada tuturan imperatif bahasa Jepang yaitu, komunikasi nonverbal dinamis yakni gestur gerakan kepala dalam bentuk tuturan imperatif fungsi perintah, permintaan, permohonan dan ajakan dan gestur gerakan tangan pada tuturan imperatif fungsi perintah, selanjutnya ada komunikasi nonverbal statis yaitu pakaian. Sedangkan komunikasi nonverbal pada tuturan imperatif dalam bahasa Indonesia ditemukan dalam sinetron Ikatan Cinta yaitu, kalimat imperatif dengan fungsi perintah, meminta, dan ajakan.

Terdapat persamaan dan perbedaan yang menjadi ciri khas secara kultur dari komunikasi nonverbal oleh masyarakat Jepang, dan masyarakat Indonesia. Berikut persamaannya, yaitu setiap terjadinya tuturan imperatif dengan komunikasi noverbal yang dilakukan pandangan menatap lawan tutur. Sedangkan perbedaannya, komunikasi nonverbal pada tuturan imperatif bahasa Jepang lebih banyak menggunakan gestur tuturan menggangguk dibandingkan dengan komunikasi nonverbal pasa tuturan imperatif bahasa Indonesia; selanjutnya komunikasi nonverbal pada tuturan imperatif bahasa Indonesia lebih banyak menggunakan gestur tuturan gerakan tubuh menggunakan telapak tangan.

Terdapat perbedaan yang menjadi ciri khas secara kultural untuk pada komunikasi nonverbal statis dalam bahasa Jepang pada pakaian, karena jenis pakaian tradisional sering ditemukan dalam kehidupan sehari-hari, selanjutnya untuk seragam sekolah siswa juga menjadi salah satu karakteristik untuk memunculkan kultural atau etnis dari negara Jepang.

\section{DAFTAR PUSTAKA}

Budyatna. 2011. Teori Komunikasi Antar Pribadi. Jakarta: Kencana Prenada Media Group.

Bunglowala, A., \& Bunglowala, A. 2015. Non verbal Communication: An Integral Part of Teaching Learning Process. International Journal of Research in Advent Technology (E-ISSN: 2321-9637). ICATEST 2015, 1-5. 
Burgoon, J. K., Laura K. G., \& Floyd, K. 2016. Nonverbal Communication. New York: Routledge.

Chomsky, N. 2006. Language and Mind Third Edition. UK: Cambridge University Press.

Creswell, J. W. 2013. Research Design Pendekatan Kualitatif, Kuantitatif, dan Mixed Edisi Ketiga. Yogyakarta: Pustaka Pelajar.

Eco, U. 2016. Teori Semiotika Signifikansi Komunikasi, Teori Kode, serta Teori Produksi - Tanda. Yogyakarta: Kreasi Wacana.

Goddard, C. (Eds) .2011. Etnopragmatics Understanding Discourse in Cultural Context. Berlin: Mourton De Gruyter.

Givens, D, B. 2015. "Measuring Gestures". (2015) Alexandra Kostic \& Derek Chadee (eds), The Social Psychology of Nonverbal COmmunication. New York: Palgrave Macmillan

Hymes, D. H. 1972. On Communication Competence. J. B. Pride and J. Holmes (Eds) Sosiolinguistic. Selected Readings. Harmondsworth: Penguin, pp. 269-293.

Kaluska, A. 2013. "the role of non-verbal communication in second language learner and native speaker discourse" (onlne) tersedia http://hdl. handle.net/11089/15153.

Knapp, M. L., Hall, J. A. \& Horgan, T. G. 2013. Nonverbal Communication in Human Interaction. USA: Wadswort

Liliweri, A. 2009. Makna Budaya dalam Komunikasi Antarbudaya. Yogyakarta: LkiS

Mahsun. 2007. Metode Penelitian Bahasa: Tahapan Strategi, Metode, dan Tekniknya edisi Revisi. Jakarta: PT Raja Grafindo Persada.

Matsumoto, D., Frank, M. G., \& Hwang, H. S. (Eds). 2013. Nonverbal Communication Science and Applications. USA: SAGE.

Nitta, Y. 1991. Nihongo no Modality to Ninshou. Jepang : Hitsuji Shobo

Pranowo. 2012. Berbahasa secara Santun. Yogyakarta: Pustaka Pelajar.

Puccinelli, N. M. 2008. "Nonverball Communicative Competence". Handbook communiation Competence. Nerlin: Mouton de Gruyter

Rahardi, R. K., Setyaningsih, Y., \& Dewi, R. P. 2016. Pragmatik Fenomena Ketidaksantunan Berbahasa. Jakarta: Erlangga.

Kunjana R. R. 2018. Pragmatik Kefatisan Berbahasa sebagai Fenomena Pragmatik Baru dalam Perspektif Sosikultural dan Situasional. Jakarta: Erlangga

Roni 2005. Jenis Makna Dasar Pragmatik Imperatif dalam Bahasa Indonesia. Verba, Vol 7, No.1, 2005 : 74-90

Saputra .2020. Penggunaan Bahasa Nonverbal dalam Interaksi Pembelajaran antara Dosen dan Mahasiswa FKIP, Universitas Sanata Darma: Kajian Etnopragmatik. Yogyakarta: Universitas Sanata Darma

Searle, J. R. 1969. Speech Acts An Essay in The Philosphy of Language. New York: Cambridge University Press.

Sudaryanto. 2015. Metode dan Aneka Teknik Analisis Bahasa. Yogyakarta:

Sugiyono. 2017. Metodologi Penelitian Kuantitatif, Kualitatif, dan $R n D$. Bandung: Alfabeta.

Spradley, P. J. 2007. Metode Etnografi. Yogyakarta: Tiara Wacana.

Yanti, N. 2020. Pemakaian Bahasa Verbal dan Nonverbal Sebagai Manifestasi Kesantunan Masyarakat Sunda di Kabupaten Ciamis : Kajian Etnopragmatik. Yogyakarta: Universitas Sanata Darma.

Zeki, C. P. 2009. The Importance of Non-verbal Communication in Classroom Management. Procedia Social and Behavioral Sciences Elsevier. 1, 2009, 1443-1449.

Joon, L. J. 2012. Ningen Kankei Ni Yoru Ishiki To Gengo Koudou No Chigai.-Nikkan Daigakusei no Kansha to Aisatsu-teido no bamen ni taisuru kōdō ochushin ni. Gengokagaku ronshuu dai 16go,1-12. 